\title{
Antibacterial activity of aqueous and alcoholic extracts of Capsella Bursa against selected pathogenic bacteria
}

\author{
Raad N. Hasan ${ }^{1, *}$, Mun 'im R. Ali ${ }^{1}$, Sinna M. Shakier ${ }^{2}$, Anfal M. Khudhair ${ }^{1}$, Moayad S. Hussin ${ }^{1}$, \\ Yasamin A. Kadum ${ }^{1}$, Ali I. Mohammed ${ }^{1}$, Ahmaed A. Abbas ${ }^{1}$ \\ ${ }^{1}$ Department of biology. Collage of science, University of Al-Mustansiryah, Baghdad, Iraq \\ ${ }^{2}$ Ministry of health $\backslash$ Teaching laboratory, Baghdad, Iraq
}

Email address:

raadalhasani@yahoo.com (R. N. Hasan)

\section{To cite this article}

Raad N. Hasan, Mun'im R. Ali, Sinna M. Shakier, Anfal M. Khudhair, Moayad S. Hussin, Yasamin A. Kadum, Ali. Mohammed, Ahmaed A. Abbas. Antibacterial Activity of Aqueous and Alcoholic Extracts of Capsella Bursa against Selected Pathogenic Bacteria, American Journal of BioScience. Vol. 1, No. 1, 2013, pp.6-10. doi: 10.11648/j.ajbio.20130101.12

\begin{abstract}
Antibacterial activity of ethanolic and aqueous extracts of Capsella Bursa were carried out against eight different species of bacteria, Gram-positive Staphylococcus aureus and Enterococcus fecalis and Gram-negative Escherichia coli, Proteus vulgaris, Serratia marcescens,Acinitobacter bumani, Klebsiella pneumoniae and Pseudomonas aeruginosa. It is active antibacterial only against gram-negative bacteria. The ethanolic and aqueous extract from the same plant showed different activities; the aqueous extract (hot) showed the same or greater activity than the ethanolic extract. by disc diffusion, hot aqueous extract 2000 and $3000 \mu \mathrm{g} / \mathrm{ml}$ inhibition zone was observed against five gram negative pathogens in almost similar pattern . Ethanolic extract was active only against Ps.aeruginosa and K. pneumoniae. The MIC and MBC values of the ethanolic and aqueous extract of Capsella Bursa was active against most bacteria. All isolates were tested by different concentration of sub-MIC of aqueous and ethanolic extracts give different activities of these concentrations to inhibit or omitting the ability of those isolates to produce virulence factors (DNase, Haemolysin production and Lipase production). Finally, the Broth dilution assay showed larger activity than the disc diffusion method.
\end{abstract}

Keywords: Antibacterial Activity, Capsella Bursa, Bacteria

\section{Introduction}

The traditional medicinal methods, especially the use of medicinal plants, still play a vital role to cover the basic health needs in the developing countries and the use of herbal remedies has risen in the developed countries in the last decades (7). Plants have the major advantage of still being the most effective and cheaper alternative sources of drugs (11). The local use of natural plants as primary health remedies, due to their pharmacological properties, is quite common in Asia, Latin America and Africa (4).

The importance of medicinal plants against pathogenic bacteria is well known (21). In this regard, according to the abundance and high potential growth Cpsella bursa pastoris plant in, this plant was selected until according to high potential of medicinal plant were use for against with some pathogenic bacteria. Capsella with the scientific name of Capsella bursa-pastoris is plant on or two years of the cruciferae family; plant genus name is taken from the word "capsella" means a bag plant.
Living organisms are unknown complex mixtures having a potentially large number of secondary metabolites. The most valuable drugs in use have been obtained from bio resources. Many new natural product-originated bioactive compounds effective in treating several diseases have been isolated from different plants, and microorganisms. They are unknown complex mixtures having a potentially large number of secondary metabolites. The simplest assays are the ones based on the mechanisms of action of a known drug (12).

In nature, plants interact with many different microbes. Some of these relationships are very complex, requiring the formation of unique structures composed of both microbe and plant gene products at the plant-microbe interface. Nitrogen-fixing bacteria and mycorrhizal fungi are two examples of microorganisms that have complex interactions with plants that greatly enhance plant growth. In recent years, a wealth of knowledge has been discovered about the microbial components essential to plant-microbe interactions (e.g., nodulation genes in Rhizobium and virulence genes 
from numerous bacterial pathogens). Likewise, our understanding of the plant genes necessary for resistance to various pathogens has taken tremendous strides with the cloning of resistance genes from several plant species (26).

This research has been focused to develop bioactive compounds from Iraqi plants as leads for drug candidates. Iraq is one of the richest countries in the world for biological sources depending on different geographical, ecological, and aquatic environments.

Capsella bursa-pastoris (L.) Medik., Brassicaceae, commonly known as shepherd's purse, is a wild plant, whose young leaves and roots have been used as an edible vegetable, eaten raw or cooked in some countries (Zennie \& Ogzewalla, 1977; Kweon et al., 1996). The nutritional composition of this species, including minerals, vitamin A, ascorbic acid, proteins, linoleic acid and $\omega 3$ polyunsaturated fatty acids, is considered to be beneficial to human health (Zennie \& Ogzewalla, 1977; Guil-Guerrero et al., 1999).

\section{Materials and Methods}

\subsection{Plant Material}

Capsella Bursa used in the traditional medicine by Iraqi people, were obtained from one source in Baghdad, Iraq. Specimen of plant was preserved and kept at the laboratory. According to their ethno pharmacological usages, plant used in this study was the same as used in herbal medicine.

\subsection{Plant Extraction}

\subsubsection{Preparation of Aqueous Plant Extracts}

Preparation of aqueous extract of Capsella Bursa was prepared according to the procedure that has been reported by Ekwenye and Njkou (2006) with some modified. A plant material was washed individually with clean sterile water and oven-dried for one hour at $160 \mathrm{oC}$. $300 \mathrm{~g}$ each of respective dry plant material was blended into fine powder and soaked in $150 \mathrm{mls}$ of distilled water (cold water extract), boiling water (hot water extract) for $24 \mathrm{hrs}$. The slurry obtained was left in clean, sterile glass container and shaken vigorously to allow for proper extraction. The slurry was filtered using a sterile muslin cloth after which the extract obtained was air dried and stored at $4 \mathrm{oC}$ until required according to the method of

\subsubsection{Ethanol Extract}

Dried of Capsella Bursa was reduced to a fine powder with a mechanical grinder. The powder plant material (200 g) was soaked in 31 of $80 \%$ ethanol and stand for 3 days. The extract was concentrated to dryness and stored at a temperature of $-4 \mathrm{oC}$ until use. Ratheesh and Helen (2007).

\subsection{Microbial Cultures}

Plant extracts were assayed for antimicrobial activity against eight species of bacteria was used as test microorganisms. The bacterial strains included Gram-positive Staphylococcus aureus and Enterococcus fecalis;
Gram-negative Escherichia coli, Proteus vulgaris, Serratia marcescens, Acinitobacter bumani, Klebsiella pneumoniae and Pseudomonas aeruginosa.. All microorganisms were clinical isolates, obtained from the Microbiology Laboratory at Department of Biology, collage of Science, University of Al-Mustansiryah, Iraq, and very carefully identified using standard microbiological methods.

\subsection{Inoculum Preparation}

Mueller-Hinton broth was applied for growing and diluting the microorganism suspensions. Bacterial strains were grown to exponential phase in Mueller-Hinton broth at $37^{\circ} \mathrm{C}$ for $18 \mathrm{~h}$ and adjusted to a final density of $108 \mathrm{CFU} / \mathrm{ml}$ by diluting fresh cultures and comparing with McFarland density.

\subsubsection{Antibacterial Activity Tests}

Determination of Minimum inhibitory concentration (MIC) and Minimum bactericidal concentration (MBC)

Broth dilution assay was carried out according to [Hassan etal.,2009]. MIC was determined by micro-dilution method using serially diluted ( 2 folds) plant extracts according to the National Committee for Clinical Laboratory Standards (NCCLS) (National Committee for Clinical Laboratory Standards, 2000). MIC of the extracts was determined by dilution of Capsella Bursa of various concentrations of 150 , $300,600,1200,2400,4800 \mu \mathrm{g} / \mathrm{ml}$ respectively. Equal volume of each extract and nutrient broth were mixed in a test tube. Specifically $0.1 \mathrm{ml}$ of standardized inoculums $(108 \mathrm{cfu} / \mathrm{ml})$ was added in each tube. The tubes were incubated aerobically at $37 \mathrm{oC}$ for $18-24 \mathrm{~h}$. Two control tubes were maintained for each test batch. These included antibiotic control (tube containing extract and growth media without inoculums) and organism control (tube containing the growth medium, saline and the inoculum). The lowest concentration (highest dilution) of the extract that produced no visible bacterial growth (no turbidity) when compared with the control tubes were regarded as MIC. However, the $\mathrm{MBC}$ was determined by sub-culturing the test dilution on to a fresh drug free solid medium and incubated further for 18-24 h. The highest dilution that yielded no signal bacterial colony on the solid medium was taken as MBC. The highest concentration of antibiotics that allowed the growth of bacteria was considered as SIC. Ability of the curing agent to cure plasmid was evaluated at SIC.

\subsubsection{Agar Diffusion Assay}

The dried plant extracts were dissolved in $85 \%$ ethanol to a final concentration of 500, 1000, 2000 and $3000 \mu \mathrm{g} / \mathrm{mL}$ and sterilized by filtration through a $0.45 \mu \mathrm{m}$ membrane filter. Agar disc diffusion assay was then carried out according to (9) using inoculums containing 108 bacterial cells on $\mathrm{MH}$ agar plates $(1 \mathrm{~mL}$ inoculum/plate). The discs (diameter, $6 \mathrm{~mm}$ ) were each impregnated with $50 \mu \mathrm{l}$ of extract $(2 \mu \mathrm{g} / \mathrm{disc})$ at a concentration of 500, 1000,2000 and 3000 $\mu \mathrm{g} / \mathrm{mL}$, placed on the inoculated agar, and incubated at $37^{\circ}$ $\mathrm{C}$ for $24 \mathrm{~h}$. Each test was carried out in triplicate with con- 
trols.

\subsubsection{Detection of Microbial Virulence factors}

To determine production of lipases, DNase and Hemolysin detection, all bacterial isolates were plated on agar plates containing the appropriate substrates as described below. Production of Lipase was assessed using single-layer agar. Single-layer agar consists of 5\% (wt/ vol) clarified butterfat and 1:7,500 Victoria blue B blended into tryptic soy agar (Difco). After incubation at $37^{\circ} \mathrm{C}$ for up to 5 days, plates were observed for the presence of colonies surrounded by dark blue zones. DNase production was determined on DNase count agar containing 10\% Toludin blue (Difco) and $1000 \mu \mathrm{g} / \mathrm{ml}$ Cephalotin (Al-Razi). After incubation at $37^{\circ} \mathrm{C}$ for 24 hours, plates were observed for the presence of colonies surrounded by clearance zones. Hemolysin detection was determined on blood agar plates (Mast, England), after incubation at $37^{\circ} \mathrm{C}$ for 24 hours, plates were observed for the presence of hemolytic surrounded the colonies (2).

\subsubsection{Effect of Sub-MIC on Microbial Virulence Factors Production}

All local bacterial isolates were growing in sub -MIC of each plant, after incubation at $37^{\circ} \mathrm{C}$ for 24 hours, transferred on agar plates containing the appropriate substrates for virulence factor detection. The highest concentration of antibiotics that allowed the growth of bacteria was considered as Sub- MIC. (Lorian, 1991)

\section{Results and Discussions}

The traditional healers use primarily water as the solvent, but we found in this study that plant extracts prepared with ethanol as solvents provided more consistent antimicrobial activity, as also reported earlier $(1 ; 9)$. The antibacterial activity of Capsella Bursa against eight selected pathogens is shown in Table 1. One isolate (Ps.aeruginosa) produced zones of inhibition in the Kirby-Bauer analysis until 2000 $\mu \mathrm{g} / \mathrm{ml}$ of the aqueous extracts . This might have resulted from the lack of solubility of the active constituents in aqueous solutions (hot and cold water extracts). Alternatively, active compound(s) may be present in insufficient quantities in the crude extracts to show activity with the dose levels employed (13).in $3000 \mathrm{~g} / \mathrm{ml}$ inhibition zone was observed against five pathogens in almost similar pattern E.coli, A.bumanii, S.marcescence, Ps.aeruginosa and K.pneumonia.

Table 1. Antibacterial activity of Capsella Bursa extracts on the test organisms.

\begin{tabular}{|c|c|c|c|c|c|c|c|c|c|c|c|c|}
\hline \multicolumn{13}{|c|}{ Extract $(\mu \mathrm{g} / \mathrm{ml})$ / Zone of inhibition $(\mathrm{mm})$} \\
\hline & 500 & & & 1000 & & & 2000 & & & 3000 & & \\
\hline & WH & WC & $\mathrm{EE}$ & WH & WC & $\mathrm{EE}$ & WH & WC & $\mathrm{EE}$ & WH & WC & $\mathrm{EE}$ \\
\hline $\begin{array}{l}\text { Staph. } \\
\text { aureus }\end{array}$ & 0 & 0 & 0 & 0 & 0 & 0 & 0 & 0 & 0 & 0 & 0 & 0 \\
\hline St.fecalis & 0 & 0 & 0 & 0 & 0 & 0 & 0 & 0 & 0 & 0 & 0 & 0 \\
\hline E.coli & 0 & 0 & 0 & 0 & 0 & 0 & 0 & 12 & 0 & 0 & 12 & 0 \\
\hline
\end{tabular}

\begin{tabular}{lcccccccccccc}
\hline $\begin{array}{l}\text { A.bumanii } \\
\begin{array}{l}\text { S.marcescenc } \\
\text { e }\end{array}\end{array}$ & 0 & 0 & 0 & 0 & 0 & 17 & 11 & 0 & 19 & 12 & 0 \\
Pr.mirabilis & 0 & 0 & 0 & 0 & 0 & 0 & 0 & 10 & 0 & 0 & 11 & 0 \\
Ps.aeruginosa 0 & 0 & 0 & 0 & 0 & 12 & 0 & 12 & 13 & 10 & 19 & 13 \\
K.pneumonia 0 & 0 & 0 & 0 & 0 & 0 & 0 & 12 & 10 & 0 & 14 & 12 \\
\hline
\end{tabular}

WH: hot water extract WC: cold water extract EE: ethanol extract.

On the other hand, Ethanolic plant extracts in $300 \mu \mathrm{g} / \mathrm{ml}$ showed some activity only against Ps.aeruginosa $(13 \mathrm{~mm})$ and $\mathrm{K}$. pneumoniae $(12 \mathrm{~mm})$, while resistant to other bacteria in the study Table1. Aksoy etal. (3) Referred that Capsella Bursa has antibacterial activity. Moreover, it can be used to treat urinary infections with haematuria, and menorrhagia. The polypeptides have a contractile action on the uterus. It is also of benefit in the treatment of hemorrhoids and varicose veins. The flavonoids have an anti-inflammatory action and the tannins are astringent. Capsella is an effective treatment for diarrhoea. It is also diuretic, due in part to the presence of mustard oil. Weak antibacterial activity mainly towards Gram-positive organisms has been reported Wikipidia (14). Whereas Park etal (10) referred to glycine rich of Capsella bursa have strong antibacterial activity against gram negative bacteria. While active ingredient of Capsella bursa is probable Tannic acid (6).

The MIC and MBC value of the cold water extract of Capsella Bursa was active against most bacteria and the MIC value range from 1200-2400 $\mu \mathrm{g} / \mathrm{ml}$, against Ps.aeruginosa and K.pneumonia was $1200 \mu \mathrm{g} / \mathrm{mL}$ while $\mathrm{MBC}$ was $2400 \mu \mathrm{g} / \mathrm{mL}$ and $4800 \mu \mathrm{g} / \mathrm{mL}$ respectively. While the MIC and MBC value against E.coli and S.marcescence in order $2400 \mu \mathrm{g} / \mathrm{mL}$ and $4800 \mu \mathrm{g} / \mathrm{mL}$ (Table 2). While the MIC and MBC value of hot water extract was active only against A.bumanii was 2400 and $4800 \mu \mathrm{g} / \mathrm{mL}$ respectively Table2 .On the other hand the same ethanolic extract value of MIC and MBC against Ps.aeruginosa was $1200 \mu \mathrm{g} / \mathrm{mL}$ and K.pneumonia was $2400 \mu \mathrm{g} / \mathrm{mL}$ Table2. Iraqi Capsella Bursa demonstrates activity against the most prevalent gram-negative bacteria namely E. coli and Ps.aeruginosa comparable with gram- positive bacteria. This result matching with Park etal. (10) They noticed that Capsella Bursa has antimicrobial peptides exhibit antimicrobial activity against Gram-negative bacteria. Lans etal. (8) referred the Wounds and injuries are treated with Capsella bursa.

All bacterial strains were tested to see the ability to produce number of virulence factors which are: DNase, Haemolysin production and Lipase production.

Results showed that isolates of S.marcescence, Ps.aeruginosa and K.pneumonia have the ability to produce DNase enzyme, while E.coli and A.bumanii loss that ability. Except A.bumanii which show haemolysin production. On the other hand all isolates showed ability to produce lipase except K.pneumonia. After all, that the positive virulence factor production isolate were tested by different concentration of sub-MIC of acqucous and ethanolic extracts to see the activity of these concentration to inhibit the 
ability of those isolates to produce virulence factors.

Table 2. Minimum Inhibitory Concentration and Minimum Bactericidal Concentration of extracts of Capsella Bursa.

\begin{tabular}{lllllll}
\hline \multirow{2}{*}{ Organism } & \multicolumn{3}{c}{ MIC $(\boldsymbol{\mu g} / \mathbf{m l})$} & \multicolumn{3}{c}{ MBC $(\boldsymbol{\mu g} / \mathbf{m l})$} \\
\cline { 2 - 7 } Staph. Aureus & +++ & +++ & +++ & +++ & +++ & +++ \\
St.fecalis & +++ & +++ & +++ & +++ & +++ & +++ \\
E.coli & +++ & 2400 & +++ & +++ & 4800 & +++ \\
A.bumanii & 2400 & +++ & +++ & 4800 & +++ & +++ \\
S.marcescence & +++ & 2400 & +++ & +++ & 4800 & +++ \\
Pr.mirabilis & +++ & +++ & +++ & +++ & +++ & +++ \\
Ps.aeruginosa & +++ & 1200 & 1200 & +++ & 2400 & 2400 \\
K.pneumonia & +++ & 1200 & 1200 & +++ & 2400 & 2400 \\
\hline
\end{tabular}

WH: hot water extract WC: cold water extract EE: ethanol extract +++ : Heavy bacterial growth.

Results of Sub-MIC test of ethanolic extract of Capsella Bursa showed ability to loss the character of DNase production in Ps.aeruginosa , S.marcescence and K.pneumonia ,while S.marcescence , Ps.aeruginosa and K.pneumonia loss the character in hot aqueous extract, the cold a aqueous extract didn't show any effect on the above virulence factor Table 3.

Table 3. Effect of plant extracts sub-MIC on virulence factor (DNase) of microorganisms.

\begin{tabular}{llllllllllll}
\hline \multirow{2}{*}{$\begin{array}{l}\text { Plant } \\
\text { extraction }\end{array}$} & \multicolumn{1}{c}{ E.coli } & A.bumanii S.marcescencePs.aeruginosa & K.pneumoni \\
\cline { 2 - 9 } & B & A & B & A & B & A & B & A & B & A \\
\hline WH & - & - & - & - & + & - & + & - & + & - \\
WC & - & - & - & - & + & + & + & + & + & + \\
$\mathrm{EE}$ & - & - & - & - & + & + & + & + & + & + \\
\hline
\end{tabular}

WH: hot water extract WC: cold water extract EE: ethanol extract + : Production - : No production A: after effecting B: before effecting.

On the other hand the ethanolic extract of Capsella Bursa showed the same ability that had been shown by the hot and cold aqueous extracts about haemolysin production, all isolates were not affected by Capsella Bursa Table 4.

Table 4. Effect of plant extracts sub-MIC on virulence factor (Hemolysin) of microorganisms.

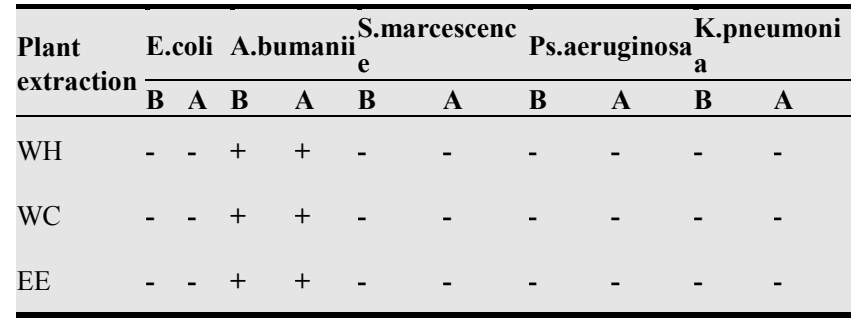

WH: hot water extract WC: cold water extract EE: ethanol extract + : Production - : No production A: after effecting B: before effecting.
While E.coli loss the ability to produce Lipase enzyme in cold aqueous extract. Where as production of this enzyme was not affected in any studied strain when Sub - MIC on ethanolic and cold aqueous extracts was done Table 5.

Table 5. Effect of plant extracts sub-MIC on virulence factor (Lipase) of microorganisms.

\begin{tabular}{|c|c|c|c|c|c|c|c|}
\hline \multirow{2}{*}{$\begin{array}{l}\text { Plant ex- } \\
\text { traction }\end{array}$} & \multicolumn{7}{|c|}{ E.coliA.bumaniiS.marcescencePs.aeruginosaK.pneumonia } \\
\hline & B A B & A B & $\mathbf{A}$ & B & $\mathbf{A}$ & B & $\mathbf{A}$ \\
\hline WH & +++ & ++ & + & + & + & - & - \\
\hline WC & +-+ & ++ & + & + & + & - & - \\
\hline $\mathrm{EE}$ & +++ & ++ & + & + & + & - & - \\
\hline
\end{tabular}

WH: hot water extract WC: cold water extract EE: ethanol extract + : Production - : No production A: after effecting $B$ : before effecting.

All the previous observation reveals the great effect of Capsella Bursa hot water extract sub-MIC on bacterial virulence factors than ethanolic extract, while cold water extract has less activity. Choi and Lee (5) reported that the number of volatile compounds of Capsella bursa was responsible of antibacterial effects. Our data agree with this result, although it is inhibition to bacterial virulence factor.

Disclosure of a novel curing agent for several virulence factors derived from plant is significant, since most of natural products are non-toxic to human and environment. The concentrations of the curing agents used in this study were sub-inhibitory (Sub-MIC), whereas bacteria were already resistant to these concentrations (MIC).

\section{References}

[1] Allero, AA. and Afolayan, AJ. Antimicrobial activity of Solanum tomentosum. Afr. J. Biotechnol. 5: 369-372. (2006).

[2] Atlas, R.M.; Parks, L.C. and Brown, A.E. (1995).laboratory Manual of Experimental Microbiology. Mosby company .Missouri. U.S.A.

[3] Aksoy, A.; Dixon, J.M. and. Hale, W.H.G . Capsella bursa-pastoris (L.) Medikus (Thlaspi bursa-pastoris L., Bursa bursa-pastoris (L.) Shull, Bursa pastoris (L.) Weber).Journal of Ecology .86 (1) :171-186.(1998).

[4] Bibitha, B.; Jisha, V.K.; Salitha, C.V.; Mohan, S. and Valsa, A.K. Antibacterial activity of different plant extracts. Short Communiaction. Indian J. Microbiol. 42: 361-363. (2002).

[5] Choi, H. S. and Lee, M. S. The effect of dispersion medium on intensity of volatile flavor components and recovery of essential oil from Capsella bursa-pastoris by steam distillation. Korean J. Food Sci. Technol., 28, 827-833.( 1996).

[6] Cndy, L.A. the antibacterial alternative: The natural guide to fighting infection and maintaining a health immune system. inner traditional.bear\&company .132, (2000).

[7] Kianbakht, S. and Jahaniani, F. Evaluation of Antibacterial Activity of Tribulus terrestris L. Growing in Iran. Iranian J. of Pharma. \& Therap., 2(1):22-24. (2003). 
[8] Lans, C.; Turner, N.; Khan, T.; Brauer, G. and Boepple, W. Ethno veterinary medicines used for ruminants in British Columbia, Canada. 3:11. (2007).

[9] Parekh, J.; Nair, R.and Chanda, S. Preliminary screening of some folkloric plants from Western India for potential antimicrobial activity. Indian J. Pharmacol. 37: 408-409. (2005).

[10] Park, C.J.; Park, C.B.; Hong, S.S.; Lee, H.S.; Lee, S.Y. and Kim, S.C. Characterization and cDNA cloning of two glycine-and histidin-rich antimicrobial peptides from the roots of shepherd's purse, Capsella bursa-pastor. Plant Molecular Biology, 44, 2, 187-197. (2000).

[11] Pretorius, C.J. and Watt, E. Purification and identification of active components of Carpobrotus edulis L. J. Ethnopharm. 76:87-91. (2001).

[12] Sener, B. and Orhan, I. Discovery of drug candidates from some Turkish plants and conservation of biodiversity. Pure Appl. Chem., 77(1) : 53-64, (2005).

[13] Taylor, J.L.S.; Rabe, T.; McGraw, L.J.; Jager, A.K. and van Staden, J. Towards the scientific validation of traditional medicinal plants. Plant Growth Regul . 34: 23-37. (2001).

[14] Wikipedia .cited by wikipedia.org/wiki/Capsella_bursa-pastoris.2008

[15] Ratheesh,M.and Helen,A.(2007).anti inflammatory of Ruta graveolens .L.on carrageenan induced paw edema in wistar male rats .Africian .J.Biotechnology .6(10):1209-1211

[16] Ekwenye, U. N. and Njkou, N. U. (2006). Antibacterial effect of Phyllanthus nirui (Chanca piedra) on three Enterobathogens in man. International Journal of Molecular Medicine and Advance Science , 2(2):184-189.

[17] Hassan, A.; Rahman, S.; Deeba, F. and Mahmud, S.(2009). Antimicrobial activity of some plant extracts having hepatoprotective effects. Journal of Medicinal Plants Research, 3(1): 020-023.

[18] Atlas, R.M., L.C. Parks and A.E. Brown, 1995. Laboratory
Manual of Experimental Microbiology. Mosby-Year Book, Inc., St. Louis.

[19] Lorian, V. Antibiotics in laboratory medicine. Baltimore: The Williams and Wilkins Company; 1991. p. 1-51.

[20] National Committee for Clinical Laboratory Standards NCCLS (2000).Methods for Dilution antimicrobial susceptibility tests for bacteria that grow aerobically: approved standards- fifth edition. NCCLS document M7-A5. NCCLS: Wayne, PA, USA.

[21] Cowan MM. Plant products as antimicrobial agents. Clinical Microbiology Review 1999; 12(4): 564-582.

[22] [22] Zennie TM, Ogzewalla D 1977. Ascorbic acid and vitamin C content of edible wild plants of Ohio and Kentucky. Econ Bot 31: 76-79.

[23] [23] Kweon MH, Kwak JH, Ra KS, Sung HC, Yang HC 1996. Structural characterization of a flavonoid compound scavenging superoxide anion radical isolated from Capsella bursapastoris. J Biochem Mol Biol 29: 423-428.

[24] [24] Guil-Guerrero JL, Giménez-Martínez JJ, Torija-Isasa ME 1999. Nutritional composition of wild edible crucifer species. J Food Biochem 23: 283-294.

[25] [25] Tsimikas S, Philis-Tsimikas A, Alexopoulos S, Sigari F, Lee C, Reaven PD 1999. LDL isolated from greek subjects on a typical diet or from American subjects on an oleatesupplemented diet induces less monocyte chemotaxis and adhesion when exposed to oxidative stress. Arterioscl Throm Vas Biol 19: 122-130.

[26] [26] Hammond-Kosack, K. E. \& Jones, J. D. G. (1997) Annu. Rev. Plant Physiol. Plant Mol. Biol. 48, 575-607.

[27] [27] Oliveira AP, Pereira D, Andrade PB, Valentão P, Sousa C, Pereira JA, Bento A, Rodrigues MA, Seabra RM, Silva BM 2008. Free amino acids of tronchuda cabbage (Brassica oleracea L. var. costata DC): Influence of leaf position (internal or external) and collection time. J Agric Food Chem 56: 5216-5221. 